Research Article

$\mathrm{J}$ Exp Clin Med

2021; 38(3): 340-344

doi: $10.52142 /$ omujecm.38.3.26

\title{
The effect of myths about sexuality and the level of knowledge about sexuality on the marital satisfaction in married couples
}

\author{
Birgül Emiroglu BAKAY ${ }^{1 \oplus}$, Eylem Ayrancı ORHON ${ }^{2}$, Kadir BAKAY ${ }^{3}{ }^{\circledR}$, Faruk OLCENOGLU $^{\circledR}$, Davut GUVEN $^{3}$, \\ Ibrahim YALCIN ${ }^{3}$, , Merve UYAR $^{3, *}$,
}

${ }^{1}$ Department of Clinical Psychology, Istanbul Arel University, Istanbul, Turkey

${ }^{2}$ Istanbul Cati Consultancy and Training Center, Istanbul, Turkey

${ }^{3}$ Department of Gynecology and Obstetrics, Faculty of Medicine, Ondokuz Mayis University, Samsun, Turkey

\begin{abstract}
\begin{tabular}{ccccc}
\hline Received: 27.02 .2021 & $\bullet$ & Accepted/Published Online: 14.03 .2021 & • & Final Version: 23.04 .2021 \\
\hline
\end{tabular}
Abstract

To look into the effect of sexual myths and level of knowledge about sexuality on marital satisfaction in married couples. The study was carried on with 104 voluntary respondents; 57 of which are married women and 47 are married men. The data has been collected with Personal Information Questionnaire, Marital Adjustment Test, Sexual Myths Analysis Questionnaire and The Golombok Rust Inventory of Sexual Satisfaction (GRISS), data has been analyzed with SPSS 15.0 software package (Statistical Package for Social Sciences). According to these findings, as the belief in sexual myths increases, the sexual satisfaction decreases; yet the increase in the belief in sexual myths does not affect the marital satisfaction. The findings implicate that as the knowledge about sexuality increases, the sexual satisfaction increases while the marital satisfaction decreases. As the number of sexual myths increases, marital adjustment decreases. The findings don't show any significant correlation between sexual satisfaction and marital adjustment.
\end{abstract}

Keywords: sexuality, sexual myths, level of sexual knowledge, marital satisfaction, sexual satisfaction

\section{Introduction}

Marriage is the smallest unit that has played a primary role throughout human development as the relational system that is built between two people who have different interests, desires and needs in order to live together, share experiences, give birth and raise children. It is a unity in which sexual needs that are kept out of all social prohibitions are met mutually and it is a contract which depends on mutual solidarity and social validation (Düzgün, 2009).

Sexual satisfaction is feeling happy and content with sexual transmission (Kayır, 2001). Sexual satisfaction defines how content one is with sexual relationship (CETAD, 2009). The main function of sexuality in marriage is sharing pleasure, improving and deepening intimacy and reducing tension resulting from the struggles of marriage and life. Sexual compatibility in marriage is an important part of the marriage process and affects contentment about marriage and marital relationship significantly. While the absence of problems in sexual function has positive impact on marriage, experiencing these problems is claimed to affect marriage negatively, drain positive feelings and marital intimacy (Vural and Temel, 2009). The depression resulting from being unable to satisfy each other sexually will affect the relationship of the married couple negatively in time (Abal1, 2007). Erbek et. al state that in Turkey and all over the world sexual behaviors are highly dominated by religious precepts, prejudices, taboos, traditions, which prevents young people from acquiring knowledge about sexuality and reproduction (Erbek, 2005). The study conducted by the Foundation of Sexuality Education and Research demonstrated that Turkish society sees the most important sources of sexual problems as $62 \%$ being uneducated and lacking knowledge (CETAD, 2009).

Sexual education can both raise individuals' awareness about the myths and prejudices they have and help professionals (trainer/therapist) to review their own ideas and beliefs. This kind of education can make sexual issues be discussed easily and prevent them to become taboos (Sungur, 1998).

\section{Materials and methods}

A signed informed content explaining the study was obtained from all participants.

\subsection{Sample}

This study aims to understand whether sexual and marital satisfaction are affected by the gender, length of marriage, number of children, level of education, believing in sexual myths and level of knowledge in married couples through 
relational scanning model. All respondents initially applied to a gynecology expert complaining of problems regarding sexual health without any physiological pathology found and thus were further referred to a psychological counseling service center for evaluation and therapy between 2017 and 2019 . Socio-demographic characteristics of the respondents are as follows: The average age of the sample is $X=33 \pm 5 . \% 39.4$ of the respondents are married for $1-5$ years, $27.9 \%$ for $5-10$ years, $19.2 \%$ for $10-15$ years and $5.8 \%$ for 20 and more years. $40.4 \%$ of the respondents are childless, $20.2 \%$ have one, $29.8 \%$ have 2 children, $9.6 \%$ have 3 and more children. Educational level of 104 respondents is as follows: $26.9 \%$ graduated from primary school, $12.5 \%$ from secondary school, $24 \%$ from high school, 30\% undergraduate studies and $5.8 \%$ from graduate studies.

\subsection{Evaluation materials}

The data of the study has been collected by Personal Information Questionnaire, Marital Adjustment Scale, Sexual Myths Analysis Questionnaire and Golombok Rust Inventory of Sexual Satisfaction (GRISS).The data has been analyzed with SPSS 15.0 software package.

\section{a- Personal information questionnaire}

The questionnaire starts with an informative statement about the objective and content of the study, the identity of the researcher, voluntary based and anonymous nature of the participation to the study. It is followed by a personal information form that asks about the socio-demographical features of the respondents. In this part, respondents are asked to state their gender, age, education level, length of marriage and number of children. Upon literature review, the researchers collated five questions about respondents' sexual lives such as who they talk to about sexual issues, who/where they first received sexual information from, whether they have sexual experience or not.

\section{b- Marital adjustment test}

In order to measure adjustment in marriage, the marriage adjustment test has been adapted to Turkish (Ergin, 2008). Marital Adjustment Test is a reliable test with fundamental and distinctive questions which was prepared by Locke and Wallace in 1959 to measure the adjustment in marriage (Açık, 2008). The test evaluates the relationship in terms of general marital satisfaction and characteristics of the marriage, family budget, emotional expression, free-time activities and agreement and disagreement in sexual issues (Açık, 2009).

\subsection{Evaluation form for level of knowledge about sexual issues}

In the research, the Evaluation Form for Level of Knowledge about Sexual Issues which was prepared by Vural was used (Vural, 2009). This form which was derived from a literature analysis includes 25 statements about male/female reproductive anatomy and physiology, contraceptive methods, sexual life, sexual dysfunction and STD. The score of the tests can vary between $0-100$.

\subsection{Sexual myths evaluation form}

This research uses the sexual myths evaluation form prepared by Zilbergeld both for women and men. This form is composed of 15 statements about various myths. It is a form that includes 15 statements such as 'Masturbation is dirty and harmful', 'The aim of good sex is sexual coitus' 'Men are always ready and eager for action' 'Sex is a natural act and cannot be learnt' (Kayır, 1998).

\subsection{5- Golombok Rust Inventory of Sexual Satisfaction (GRISS)}

It was developed to evaluate the quality of sexual relationship and sexual dysfunction for heterosexual couples. The overall score gives a general view about the quality of sexual functions and the sub scores give more detailed information about various aspects of the relationship. Some sub scores can also be used to diagnose a dysfunction (Vural, 2009). The Turkish version of the form was tested for reliability and validity by Tuğrul et al. in 1993 and was standardized to be usable in Turkish culture (Tuğrul et al., 1993; Yılmaz et al., 2010).

\section{Results}

Table 1 shows the results of Pearson Correlation Coefficient that has been calculated for all tests in the research. The results show a significant negative correlation between GRISS and Sexual Myth Test scores $(r=-0.58, \mathrm{p}<0.05)$. According to that, as the belief in sexual myths increases, the scores of sexual satisfaction decreases. According to results there is a significant positive correlation between GRISS and scores of sexual knowledges $(r=0.47, p<0.05)$. In other words, as the level of knowledge about sexual issues increases, the scores of sexual satisfactions increase too. The results show a weak negative correlation between marital adjustment and sexual myths inventory scores $(\mathrm{r}=-0.32, \mathrm{p}<0.05)$. As the sexual myths increases, marital adjustment decreases. There is a significant negative correlation between marital adjustment and level of sexual knowledge $(\mathrm{r}=-0.19, \mathrm{p}<0.05)$. Thus, as the knowledge about sexual issues increases marital adjustment decreases.

Table 1. The correlation results between tests in the research***

\begin{tabular}{|l|c|c|c|c|}
\hline GRISS total (n:104) & GRISS Total & Sexual Myth & Marita Adjst. & Sexual Knw. \\
\hline GRISS & 1.000 & $-.582^{* *}$ & $.484^{* *}$ & $.473^{* *}$ \\
\hline Sexual Myth & $-.582^{* *}$ & 1.00 & $-.326^{* *}$ & $.391^{* *}$ \\
\hline Marital Adjustment & $.484^{* *}$ & $.326^{* *}$ & 1.00 & $-.195^{* *}$ \\
\hline Sexual Knowledge & $.473^{* *}$ & $.391^{* *}$ & $-.195^{* *}$ & 1.00 \\
\hline
\end{tabular}


There isn't a significant correlation between GRISS and marital adjustment scores; in other words, between sexual satisfaction and marital adjustment $(\mathrm{r}=0.48, \mathrm{p}>0.05)$. According to gender variable, independent group t-test applied to the sexual satisfaction total score indicated a significant difference $(p<0.01)$. This difference was in women's favor. The sexual satisfaction scores of women were higher than men's. In addition to that, the sexual myths scores of women were higher, as well $(\mathrm{p}<0.05)$. Yet, men's scores in knowledge about sexual issues were higher.

According to ANOVA Test results for Education Level and tests used in the research (GRISS, Sexual Myths Evaluation Form, Evaluation Form for Level of Knowledge about Sexual Issues and Marital Adjustment) there is a significant difference between sexual satisfaction, belief in sexual myths, marital adjustment of respondents and their education level $(p<0.01)$. The sexual satisfaction score of the primary school graduates was $(X=76.24)$, the score of high school graduates was $(X=$
68.21), the score of university and higher education graduates was $(X=56.02)$. Taking the results of the correlation between sexual myths and education level, it is seen that the scores of believing in sexual myths is higher in university and higher education graduates $(X=25.76)$ compared to the scores of high school graduates $(X=22.84)$ and scores of the primary school graduates $(X=19.04)$. When the marital adjustment and education level are analysed, the scores of primary school graduates $(X=41.16)$ and high school graduates $(X=38.90)$ were higher than university graduates $(X=37.00)$. The results didn't show any difference between education level and level of knowledge about sexual issues ( $\mathrm{p}>0.05$ ).

According to the results of Scheffi test analyzing the difference for education levels, it is demonstrated that sexual satisfaction scores were higher in primary school graduates compared to the high school and university graduates. Table 2 shows the distribution of sample group according to sexual life information for genders in frequency and percentage.

Table 2. Distribution of individuals according to the characteristics of sexual life

\begin{tabular}{|c|c|c|c|c|}
\hline \multirow{2}{*}{ CHARACTERISTICS } & \multicolumn{2}{|c|}{ Frequency (n) } & \multicolumn{2}{|c|}{ Percentage (\%) } \\
\hline & $\mathbf{F}$ & $\mathbf{M}$ & $\mathbf{F}$ & $\mathbf{M}$ \\
\hline \multicolumn{5}{|c|}{ Importance of Sexuality } \\
\hline None & 11 & - & 19.3 & - \\
\hline A little & 18 & 7 & 31.6 & 14.9 \\
\hline Indecisive & 3 & 3 & 5.3 & 6.4 \\
\hline Quite & 16 & 23 & 28.1 & 48.9 \\
\hline A lot & 9 & 14 & 15.8 & 29.8 \\
\hline \multicolumn{5}{|c|}{ Having Knowledge About Sexuality Before Marriage } \\
\hline None & 17 & 1 & 29.8 & 2.1 \\
\hline A little & 20 & 12 & 35.1 & 25.5 \\
\hline Indecisive & 3 & - & 5.3 & - \\
\hline Quite & 12 & 24 & 21.1 & 51.1 \\
\hline A lot & 5 & 14 & 8.8 & 21.3 \\
\hline \multicolumn{5}{|c|}{ Being Ashamed of Talking About Sexual Issues } \\
\hline Yes & 30 & 12 & 52.6 & 25.5 \\
\hline No & 27 & 35 & 47.4 & 74.5 \\
\hline \multicolumn{5}{|c|}{ The Person to Talk to About Sexual Issues } \\
\hline Girlfriend & 39 & 6 & 68.4 & 12.8 \\
\hline Boyfriend & 1 & 27 & 1.8 & 57.4 \\
\hline Mother/Father & 1 & 1 & 1.8 & 2.1 \\
\hline Sibling & 7 & 2 & 12.3 & 4.3 \\
\hline Others & 9 & 11 & 15.8 & 23.4 \\
\hline \multicolumn{5}{|c|}{ The Source to Learn the First Sexual Information } \\
\hline School/Lesson & 4 & 3 & 7 & 6.4 \\
\hline Books/Magzines & 8 & 9 & 14 & 19.1 \\
\hline Tv- Media & - & 3 & - & 6.4 \\
\hline Friends & 37 & 26 & 64.9 & 55.3 \\
\hline Mother/Father & 2 & - & 3.5 & - \\
\hline Others & 6 & 6 & 10.5 & 12.8 \\
\hline Total & 57 & 47 & 100 & 100 \\
\hline
\end{tabular}


For the question 'How important is sexuality for you?' 19.3 $\%$ of female respondents said none, $31.6 \%$ said a little, $5.3 \%$ said indecisive, $28.1 \%$ said quite and $15.8 \%$ said a lot. $14.9 \%$ of male respondents said a little, $6.4 \%$ said indecisive, $48.9 \%$ said quite and $29.8 \%$ said a lot. To the question 'How knowledgeable were you before you got married?' $29.8 \%$ of female respondents said none, $35.1 \%$ said a little, $5.3 \%$ said indecisive, $21.1 \%$ said quite and $8.8 \%$ said a lot. $2.1 \%$ of male respondents said none, $5.5 \%$ said a little, $51.1 \%$ said quite and $21.3 \%$ said a lot. When asked 'Are you ashamed of talking about sexual issues?' $52.6 \%$ of female respondents said yes and 47. $4 \%$ said no while $25.5 \%$ of male respondents said yes and $75.5 \%$ said no. To the question 'Who do you talk to about sexual issues?' $68.4 \%$ of female respondents said with my girlfriend, $1.8 \%$ said with my boyfriend, $1.8 \%$ said with my mother/father, $12.3 \%$ said with my sibling, $16.8 \%$ said others. $2.8 \%$ of male respondents said with my girlfriend, $57.4 \%$ said with my boyfriend, $2.1 \%$ said with my mother/father, $4.3 \%$ said with my sibling, $23.4 \%$ said others. When asked 'Where did you get your first information about sexuality? $7.0 \%$ of female respondents said school, $14.0 \%$ said books/magazines, $64.9 \%$ said friends, $3.5 \%$ said mother/father, $10.5 \%$ said others.6.4\% of male respondents said school,19.1\% said books/magazines, $55.3 \%$ said friends, $6.4 \%$ said media/tv, $12.8 \%$ said others According to this, sexuality is more important for male respondents than female respondents. Most of both female and male respondents received their first sexual information from their friends and they both mostly talk to their friends about sexual issues. While most of the female respondents stated that they are ashamed to talk about sexual issues, most of the male respondents stated that they didn't feel ashamed.

\section{Discussion}

This study has looked into the effect of level of knowledge about sexuality and sexual myths in married couples on sexual satisfaction and the effect of level of knowledge about sexuality and sexual myths in married couples on marital satisfaction. The results have shown that as the scores of knowledge level increase, the scores of marital adjustment increase, as well. These findings are parallel with the previous findings that say that marital satisfaction and sexual satisfaction are directly proportional; if one is bad the other is bad too (Huston and Vangelesti, 1991; Gülsün et al., 2009; Pande et al., 2011). The scores for level of knowledge about sexual issues were higher in men than women. This may be the result of the fact that sexuality is seen as a taboo for women in our country and because of the myths which say that women who are closely interested in these issues will be regarded negatively, which estranges women from the sexuality. This was also suggested by Curtin as a possible problem in certain cultures (Curtin et al., 2011).

Besides, that might be related to the fact that men are interested in sexual issues starting from adolescence and before, and this is seen as normal by the society and they can also access sources and publications easily. According to the results, the sexual satisfaction scores are higher in primary school graduates than high school and university graduates. This can be explained by the fact that as the education and experience level of the individuals increase, their expectations about sexual satisfaction like many other issues increase, too. In the current study, the data has been collected from married individuals, yet their spouses haven't been included in the research. Halloran claims that according to the system approach the spouses can affect each other (Halloran, 1998). Thus, in further studies getting information related to the spouses and incorporating them into the study may enrich the research.

\section{Conflict of interest}

None to declare.

\section{Acknowledgments}

None to declare.

\section{References}

1. Abal1, S., Kömürcü N., 2007. Evlilikteki cinsel sorunlar boşanma nedeni midir? Hemşire Çalışma Grubu / Kadın Cinsel Sağlığı. 270-272.

2. Açık, Ö., 2008. Evlilik uyumu ve bağlanma stilleri arasındaki ilişki. Uzmanlık tezi, Ege Üniversitesi Sosyal Bilimler Enstitüsü.

3. Cinsel Eğitim Tedavi ve Araştırma Derneği (CETAD), 2009. Cinsel yaşam ve sorunları rehberi. Cinsel sağlık ve üreme sağlığ alanında ulusal ve yerel medya yoluyla savunuculuk projesi, (11-15 and 43-48).

4. Curtin N., Ward ML., Merriwether A., Caruthers A., 2011. Femininity Ideology and Sexual Health in Young Women: A focus on Sexual Knowledge, Embodiment, and Agency. Int. J. Sex. Health. 23(1), 48-62.

5. Düzgün, G., 2009. Evli kişilerde depresyon, ilişkiye İnanç, kendini ayarlama düzeyinin evlilik uyumu ile ilişkisi. Yüksek Lisans Tezi, Ankara Üniversitesi Sosyal Bilimler Enstitüsü.

6. Erbek E., Beştepe E., Akar H., Alpkan L., Eradamlar N., 2005. Cinsel ve çift uyumu arasındaki ilişki: Üç grup evli çiftte karşılaştırmalı bir çalışma. Düşünen Adam. 18(2), 72-81.

7. Ergin, N., 2008. Evli ve boşanmış kişilerin evlilik uyumu ve cinsiyetçilik açısından karşılaştırılması. Yüksek lisans tezi, Ankara Üniversitesi Sosyal Bilimler Enstitüsü.

8. Gülsün, M., Ak M., Bozkurt A., 2009. Psikiyatrik Açıdan Evlilik ve Cinsellik. Psikiyatride Güncel Yaklaşımlar. 1, 68-79.

9. Halloran, E.C., 1998. The role of marital power in depression and marital distress. Am. J. Fam. Ther. 26, 3-14.

10. Huston, T.L., Vangelesti, A.L., 1991. Socioemotional behavior and satisfaction in marital relationships: A longitudinal study. J. Pers. Soc. Psychol, 61(5), 721-733.

11. Kayır, A., 2001. Psikiyatri ders notu. İstanbul Tıp Fakültesi Psikiyatri Anabilim Dalı, İstanbul, İstanbul Üniversitesi Yayınları, 1-3.

12. Kayır A., 1998. Cinsellik kavramı ve cinsel mitler, cinsel işlev bozuklukları monograf serisi (1): Cinsel sorunlara genel yaklaşım, İstanbul Roche Müstahzarları Sanayi AS, 30-35.

13. Pande Rohini Prabha, Falle Tina Y., Rathod Sujit, Edmeades Jeffrey, Krishnan Suneeta 2011 'If your husband calls, you have to go': understanding sexual agency among young married 


\section{Bakay et al. / J Exp Clin Med}

women in urban South India. Sex. Health. 8, 102-109.

14. Sungur, M., 1998. Cinsel Eğitim. Klinik Psikiyatri. 2, 103-108.

15. Tuğrul C., Öztan N., Kabakçı E., 1993. Golombok-Rust Cinsel Doyum Ölçeği'nin Standardizasyon çalışması. Turk. Psikiyatri Derg, 4, 83- 88 .
16. Yılmaz E., Zeytinci E., Sarı S., Karababa İ.F., Çilli A.S., Kucur, R., 2010. Konya il merkezi'nde yaşayan evli nüfusta cinsel sorunların araştırılması. Türk Psikiyatri Dergisi, 21(2) 126-134.

17. Vural, B.K., Temel, A.B., 2009. Effectiveness of premarital sexual counselling program on sexual satisfaction of recently married couples. Sex. Health. 6, 222-232. 